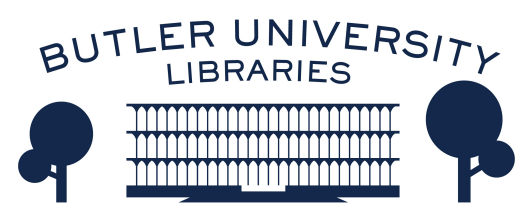

Journal of Hindu-Christian Studies

Volume 24

Article 3

November 2011

\title{
Dualities and Women's Wisdom in Hinduism: Voss Roberts on Lallesvari of Kashmir
}

Lance Nelson

Follow this and additional works at: https://digitalcommons.butler.edu/jhcs

Part of the Religion Commons

\section{Recommended Citation}

Nelson, Lance (2011) "Dualities and Women's Wisdom in Hinduism: Voss Roberts on Lallesvari of Kashmir," Journal of Hindu-Christian Studies: Vol. 24, Article 3.

Available at: https://doi.org/10.7825/2164-6279.1480

The Journal of Hindu-Christian Studies is a publication of the Society for Hindu-Christian Studies. The digital version is made available by Digital Commons @ Butler University. For questions about the Journal or the Society, please contact cbauman@butler.edu. For more information about Digital Commons @ Butler University, please contact digitalscholarship@butler.edu. 


\title{
Dualities and Women's Wisdom in Hinduism: Voss Roberts on Lalleśvarī of Kashmir
}

\author{
Lance Nelson \\ University of San Diego
}

THE stereotype of the dualist West verses the nondualist East has far outlived whatever usefulness it may have had. As one who has been concerned with this issue in my own work, ${ }^{1}$ I am happy to see Michelle Voss Roberts addressing it methodically and effectively in her Dualities: A Theology of Difference. She gives us in this book a multi-leveled study that advances this discussion dramatically on a number of interconnected fronts, both theological and ethical, encompassing wideranging feminist, ecological, and social justice concerns. I find myself in enthusiastic agreement with much that she writes. In what follows I will offer some reflections on a rather focused segment of Voss Robert's broader discussion, namely, the contribution of the Kashmiri poet-saint Lalleśvarī, an aspect of the book that was of particular interest to me given my training in medieval Hindu theology.

The book takes as its primary dynamic a comparative dialogue between the theologies of two medieval woman: Mechthild of Magdeburg, a thirteenth century beguine Christian, and Lalleśvarī, a fourteenth century Hindu standing in the Kashmir Saiva tradition. The thought of Mechthild, Voss Roberts argues, shows that Christianity is not necessarily dualistic. The thought of Lalleśvarī demonstrates, in turn, that Hindu nondualist visions are not necessarily monisms. Consideration of the respective visions of these two theologian-mystics assists in "dismantling" (36) the commonly held view that the West is dualistic and the East is monistic. In the work of Mechthild and Lalleśvarī, Voss Roberts identifies and explores a middle ground (or "third space," 24) between dualism and monism, in which dualities are not necessarily reified into dualisms and the relationship between God and world and God and soul involves neither sharp discontinuity nor complete identity. She finds in Mechthild and Lalleśvarī suggestions of a new language for speaking, from that middle ground, of differences that are not crystallized into razoredged dualisms. Leaving aside the normative ethical implications that Voss Roberts draws out, which are important but which I cannot address here, such is the central thesis of the book. So far, I am completely on board.

An additional argument in this book is that we are able to glean new theological insights by straying beyond the bounds of official, maledominated theology and attending to the voice of marginalized religious women. Mechthild and Lalleśvarī are both "outsiders within" in many respects. Voss Roberts is eloquent and convincing in speaking of the numerous ways in which women in general, and these women in particular, have been ill-treated and disempowered by their respective religious traditions, not only sociologically but theologically, especially in their exclusion from the ranks of acceptably representative theologians of the normative traditions. It is clear that in both traditions religious authority

Lance E. Nelson is professor of theology and religious studies at the University of San Diego, U.S.A. He received his Ph.D. in Religious Studies from McMaster University. Dr. Nelson's research focuses on medieval Hindu theology, particularly Advaita Vedānta, and the relation of religion and environmental activism. His writings on aspects of South Asian religious and philosophical thought have appeared in books, reference works, and scholarly journals in the United States and India. He edited Purifying the Earthly Body of God: Religion and Ecology in Hindu India (1998). Dr. Nelson is a former president of the Society of Hindu-Christian Studies. 
has been constructed as masculine. The book advances the further claim that the signal contributions of these women arise, to a considerable extent, precisely out of their status as women, women who are marginalized. The concept of "women's wisdom" is evoked more than once. While I am completely sympathetic to this idea, and willing to allow-or even betthat this distinctively gendered insight is there, I'm not at all sure, in relation to Lalleśvarī, that Voss Roberts has successfully identified what this contribution is. So I would like to raise a few questions.

\section{The Matter of the Tattvas}

Key to the book's search for the "third space" between dualism and monism is the finding, well-documented by the author, that both Mechthild and Lalleśvarī envision a relation between divinity and the world of diversity characterized by a profoundly permeable continuity. In both women, Voss Roberts finds an "interplay of immanence and transcendence" involving "layered cosmologies that express relative levels of perception of the divine-not levels of separation from God" (73).

One of the most compelling segments of the author's discussion of Lalleśvarī is her analysis of the Kashmir Śaiva doctrine of the thirty-six tattvas. Here, Voss Roberts gives us fresh insight into Kashmir Śaiva metaphysics and spirituality. The tattvas are, as the author very clearly explains, "psychological levels of awareness as well as cosmic levels of being" (66), involving a relatively complex succession of emanational stages between the absolute oneness of the transcendent, Supreme Siva (paramaśiva) and full-blown multiplicity. I have never been one for baroque overcomplexity in religious thinking, and I confess I have had a tendency, in my studies of Kashmir Saivism, to pass quickly over the tattva system, never quite fully appreciating the many subtle distinctions. In this respect, the author's reading has been of immense assistance to me. Her analysis shows how the system allows "multiple levels from which one can view the world," enabling the liberated individual-who sees the world as it truly is-to "move between the tattvas while retaining the all-pervasive consciousness." The result is that "Lalleśvarī can view the world from the various tattvas, seeing the continuum of God-world unity in its many degrees of difference" (73-74). The analysis is insightful, and speaks directly to the point of dualities that are not dualisms.

This means, however, that Voss Roberts's understanding of Lalleśvarī as expounding a vision of multi-leveled continuity between the divine and the mundane becomes heavily dependent upon reading Lalleśvarî's vākhs, or "sayings," in light of the tattva doctrine. Now the tattva doctrine, while certainly alluded to in the $v \bar{a} k h s$, is not expounded therein or even mentioned directly. The doctrine is, in fact, straight out of the standard, main-stream textbooks of Śaivism, authored and extensively commented upon in Sanskrit by the male elite and formulated centuries before Lalleśvarī's time. As the author rightly observes in a note (n. 27 , p. 173), the doctrine can be found summarized in "any introduction" to Kashmir Śaiva theology. The question then arises, in what sense is this wisdom, systematized by a male elite, particular to the experience of a marginalized woman?

The same question arises in relation to the application of the Śaiva scheme of malas, or impurities, to Lalleśvarī’s thought. Voss Roberts explains this scheme nicely and rightly attributes it to "Lalleśvarî's philosophical tradition" (24). This is, of course, not a tradition that she initiated, but one within which she stood, by upbringing and training under her guru, Siddha Śrikantha. This was, for better or worse, a maledominated tradition. ${ }^{2}$

\section{Fluidity and "Women's Wisdom"}

Much of the discussion in this book centers around metaphors of fluidity and flow as expressive of the nature of the divine. Such fluid imagery, Voss Roberts argues cogently, may facilitate the inclusion of "multiplicity at the very heart of divine being and becoming" (154). By exploring the manifestation of this imagery in the religious experience of two particular women, the author is able to dramatically underline its theological potential. 
It evokes, as she points out, a vision of reality composed richly of shifting, permeable dualities that avoid becoming essentialized, hierarchically structured dualisms.

Voss Roberts suggests that the metaphors of fluidity in theologies of both women are "rooted in bodily experience." More specifically, they "correlate to a heightened awareness of women's bodily experiences as notoriously leaky and fluid" (15). In exploring this imagery in Lalleśvarī, Voss Roberts argues further that the saint's "fluid way of thinking puts a unique stamp on a traditional Kashmir Śaiva teaching" (30).

My view on this is that the case is perhaps less convincing for Lalleśvarī than it may be for Mechthild. A reading of the $v \bar{a} k h s$ (it does not take long, there are but 138 in the latest critically sifted text ${ }^{3}$ ) shows that images of flow and fluidity are not all that prominent. There are three or four evocations of lake, sea, or ocean, as Voss Roberts notes. I wonder, however, if they should be read in the way Voss Roberts suggests. They are not always used to portray the divine, neither are they entirely positive. For example, "Consider the mind like an ocean[.] If not restrained, fiery words will issue forth in anger" (O 140). ${ }^{4}$ This says nothing about the liquidity or flow of the divine. Elsewhere, Lalleśvarī uses the image of creation as an ocean across which God is ferrying her (K 1) or a lake in which all creatures fall "as soon as born" (K 113). There is a certain kind of fluidity in this water imagery, but it is not a positive celebration of the continuity between divine unity and the diversity of creation. Nor is this metaphor unique to our poet. The sea or ocean does not, in this context, depict "the separation and the return to the Self" (30). What we have here is rather the ancient, pretty much pan-Indian image-a negative one-of the ocean of samsāra, in which we are all drowning and from which we need saving (see, e.g., Bhagavadgītā 12.7). Lalleśvarī herself calls it the "sea of delusion" (K 13, O 147). I am not clear as to how this imagery contributes to any master metaphor of "divinity is a fluid" (151).

This is not so say, however, that appropriate imagery cannot be found in Lalleśvarī's vākhs. Voss Roberts points to the analogy of water transformed into ice and snow ( $\mathrm{K} 83$, O 39), which Lalleśvarī uses to suggest that the one Divine, like water, may assume multiple forms. This is a striking image, and it provides some support for Voss Robert's thesis. Alas, however, it is not original with Lalleśvarī. It is a relatively common trope in the Kashmir Saiva (and indeed the broader Hindu) tradition. Thus Kșemarāja, in his Śivasūtravimarśinī, quotes an unnamed àgama:

Oh dearest! For him [sic] who knows from scripture and the word of the guru that snow is [a form of] water, nothing remains to be done. This is his final birth. ${ }^{5}$

Lalleśvarī speaks elsewhere of the supreme Consciousness as a "lake of nectar" (amrta saras) in which she gets "immersed" (K 130, O 58). Again, however, this language is not unique to this particular theologian. Utpaladeva, a pillar of official Kashmir Śaivism, lived and wrote some five or six centuries prior to Lalleśvarī (c. 900-950 CE). In his Śivastotrā valĭ, he envisions "this whole world . . - merged into a lake of nectar (sudhā-sarasi, 5.26). ${ }^{6}$ To be sure, Lalleśvarī, having realized the divine Self, is able to find "this worldly ocean" (bhava-saray) a place to "laugh and play" (O 29). Yet Utpaladeva long before her sings to his Lord: "Your devotees frolic in this ocean of the world (samsāra-saras), brimming with the cool nectar that flows from your limbs" (18.9). He speaks directly of Śiva as an "ocean of consciousness-bliss (cid-ānanda-jaladhi) . . . emitting floods of nectar (amrta-pūra) drowning the whole world" $(3.6,19.6)$. "Everything," he exults, "is saturated (apluta) with you alone" (12.1). It is not difficult to get the impression that metaphors of fluidity are more dominant in Utpala than in Lalleśvarī. Even more striking, in terms of its fluid imagery, is a passage in the Sanskrit Stavacintāmaṇi by the early Śaiva preceptor Bhaț̣a Nārāyana (late ninth-early tenth cent. C.E.), which describes Śiva as "pouring fourth (siñcan) the universe in all directions with an uninterrupted flow of Consciousness (samivid-dhārā-dhoran̄i).", $\quad$ Likewise Abhinavagupta (10th cent. C.E.), perhaps the 
most important theologian of Kashmir, at Tantrāloka 8.2:

I worship the body of Bhairava [Śiva], manifest before my eyes as the universe, taking form as the flood (ogham) of the nectar of Consciousness (cid-rasa) [becomes] condensed (āśyānam). ${ }^{8}$

Voss Roberts cites the idea that "individual selves are waves or foam on the ocean of the Self" or "thought constructs arise like waves on a lake, leading to a disturbance of one's sense of unity with pure consciousness" (31) as suggestive of Lalleśvarī's "fluid thinking." So far as I can determine, however, this wave metaphor is not to be found in the vākhs of our Kashmiri poet-saint, although it is a relatively common trope in the wider world of Hindu thought-e.g., in the Yoga Vãsiștha (10th-12th century) - and in earlier Saiva texts. Thus at Vijñānabhairava Tantra 110 an ecstatic yogin declares:

Like waves from water, flames from fire, and light from the sun, the waves of the universe (viśva-bhangyah) issue forth from me, who am Bhairava [Śiva]. ${ }^{9}$

Lalleśvarī's uses the language of "void (śunya) merging in the void" repeatedly in the $v \bar{a} k h s$ (e.g., O 40-41). Voss Roberts (31) finds this evocative of "dissolution or immersion," which it may well be. Still, the language of being dissolved, melted, or immersed (linna, nimagna, etc.) in God is everywhere in Sanskrit religious literature. The prescriptive texts of the Śaiva tradition hold samāveśa, "immersion" or "absorption" in Paramaśiva to be the practitioner's goal. In respect of the void, moreover, one should be sure that readers understand that it is not here the watery and dark deep over which the spirit of God moves in Genesis 1. Súnya is important in Śaiva texts as a technical term marking several stages in the adept's ascent to complete Śivahood (as articulated, for example, in the Svacchanda Tantra). It is generally suggestive complete absence of thought and empirical experience. Paramaśiva is termed śūnyāti-śūnya, the "Void beyond the void."10 The concept, defined somewhat differently, was of course also central in Mahayāna Buddhism, which flourished in Kashmir from the early centuries C.E.

Given the limited, fragmentary, and uncertain nature of our sources for Lalleśvarī's theology - the 138 or so $v \bar{a} k h s^{11}$-it is perhaps inevitable that interpretation relies heavily on reference to the wider frame of Kashmir Śaivism. This is the approach taken by Kashmiri scholars such as Kaul and Odin, and this is what Voss Roberts has done, as she readily admits. "Lalleśvarī's tradition," she writes, "imagines the difference and continuity between the absolute and the cosmos in fluid terms" (59, emphasis mine). I think the assumption that Lalleśvarī is operating largely out of the fund of ideas she inherits is a good one. This makes it more difficult, however, to argue that metaphors of fluidity, embedded abundantly as they are in the larger Saiva tradition, should be taken as exemplifying a special kind of women's wisdom that puts a "unique stamp" (30) on that tradition.

\section{Lalleśvarī’s Contribution}

So what is Lalleśvarī’s distinct contribution as a woman? This is not an easy question, and in my view it would take a wide-ranging study of the relevant Sanskrit and Kashmiri (and likely Persian) literature to answer it definitively. In our panel discussion, the poet's extensive use of the concrete imagery of everyday life was cited as a possibility. Perhaps, but the same could surely be said of the vernacular poetry of Kabīr, Raidās, or the Bāuls of Bengal. Does it lie, then, in Lalleśvarī's concept of sahaj, the "natural" path to realization of God? Voss Roberts (2930, 92-95) emphasizes, I think rightly, the idea of sahaj as key to understanding Lalleśvarī, but does not connect it specifically with her experience as a woman. It would be a difficult connection to establish, because this polysemous term has a lengthy history in Hindu, and especially Buddhist, tantra. It would again require a lengthy survey to sort out what might be unique in Lalleśvarī's usage.

Odin, upon whose recent book-length study of Lalleśvarī Voss Roberts in part depends, has 
some thoughts on this subject. Like Voss Roberts, Odin works out of feminist concerns, and she seeks as well to discover a "third space" in the Kashmiri poet's work, albeit of a somewhat different kind. ${ }^{12}$ Because, in her view, the Siva/Śakti binary winds up defining the feminine in terms of the masculine, she looks for a transcendent locus beyond that pairing. She finds this in the already mentioned image of the void (śūnya), a "new space"13 which transcends gender distinctions. Odin quotes Lalleśvarī, who proclaims of that highest state: "Shiva and Shakti don't live there." ${ }^{, 14}$ But in this case too, as Odin acknowledges and indeed extensively documents, the concept originated in the Sanskrit texts. It is part of a broader Kashmir Śaiva vision, in which Lalleśvarī participates.

Odin suggests that the aspect of Lalleśvarī's work that most distinguishes her from the received authorities of her tradition, and perhaps most clearly emerges from her experience as a woman, is her valuation of the world, which is generally less affirmative than is typical in Kashmir Śaivism. The high tradition of Śaiva gurus, while allowing for a preliminary disparagement of the world for the sake of entrylevel ascesis, tends on the whole to celebrate the world, understanding it as the play of Sakti and hence as fully divine, at least as perceived by accomplished yogins and yoginīs. Hence we have the tantric license that gives certain practitioners permission for meditative ritual indulgence in forbidden pleasures; hence also the extraordinary history of accomplishment in aesthetic theory built up by such Kashmiri authors as Ānandavardhana (ninth century C.E.) and, most especially, Abhinavagupta. ${ }^{15}$ Odin. however, reads in Lalleśvarī

a deliberate attempt ... to stay locked out of any aesthetic experience of the world. Her most profound verses then reflect her desire to lose herself in mystical experience rather than to use it as the ground to lead a more fulfilling material existence. ${ }^{16}$

Voss Roberts-at least in part-agrees. She sees in the poetry evidence of "disenchantment with the world" (64) and allows that Lalleśvarī often experiences it as ephemeral, wearying, delusive. While Lalleśvarī expresses joy at playing and laughing in the world, as we have seen, and sees the universe at times as "permeated with Shiva" (O 39), a reader cannot help but notice how she longs "to go home" (O $2)$ or "find [her] shore" (O 50, 51), how she sees everything "as ashes" (O 124), how she emphasizes dying to the world (O 37, 58, 145), and how she is fascinated with the idea of merging with the void (O 34, 40, 41, 44, 49, 8586), perhaps her favorite image. ${ }^{17}$

Although it may divert us from our theological focus, I sense that a turn to the sociological is here unavoidable. Contrast the image of Lalleśvarī as a homeless ascetic, defying convention by wandering naked, with that of the doyen of the Kashmir Śaiva tradition, Abhinavagupta. Although he chose to remain unmarried (an option available to him as a male Brahmin), one would not call him an ascetic. We are told that he lived variously in his ancestral home in Pravarapura (now Srinagar), in the homes of several of his teachers, and in the homes of his disciples. Having come from a family of scholars made wealthy by royal patronage, he had the best possible education, his written output was prodigious, his reputation and prestige was vast. In such a position, he could afford, one imagines, the luxury of aesthetic appreciation. $\mathrm{He}$ is most famously portrayed-by his disciple, Madhurāja Yoginas attired in white a silk dhotī (loincloth), seated in on a golden dais in a yogic posture, beneath a sumptuous pavilion hung with beautiful paintings and perfumed with flowers, incense, and sandalwood, surrounded by disciples and admirers, attended by two dītīs (female consorts) holding jugs of wine and betel nut, his right hand in the mudra (gesture) of knowledge and his left hand languidly plucking the strings of a vinna (lute), his eyes blissful as he savors the instrument's sound. ${ }^{18}$ Lalleśvarī's situation could hardly be more different. As a woman in fourteenth century Kashmir, she was locked into a social location that did not offer the options open to Abhinavagupta. Forced into an archetypically oppressive marriage, with husband at best indifferent and in-laws actively hostile to her spiritual pursuits, her only route of escape was stepping outside of all available 
systems of social support, flouting convention (as symbolized by her legendary nakedness) by becoming a wandering renouncer. This was, as Odin points out, "the only way that was available to her in the historical period that she occupied" ${ }^{\prime 19}$ It is no wonder that her view of the world is not as celebratory as that of vastly more comfortable male scholar-preceptors of her tradition. It is interesting in this connection that the other major female poet-saint of Kashmir, Rūpa Bhavānī (c. 1621-1721), adoptedaccording to the hagiographies - the life of a solitary ascetic after escaping a marriage situation strikingly similar in detail as well as overall oppressiveness to that of Lalleśvarī, whom she took as her guru. ${ }^{20}$

\section{Conclusion}

This book represents an important contribution to comparative theology, and along the way it offers any number of valuable insights in feminist theology, eco-theology, and related realms. There is much in this book with which I am in delighted agreement, and indeed much that I have learned from engagement with it. The author's main concern, per the book's title, is the theological question of overcoming the dualism/monism dichotomy and preserving space for fluid, softly focused dualities. Again, I find myself voicing an enthusiastic "Yes!" to much of the discussion. It seems to me, however, that the feminist lens is less useful in evaluating Lalleśvarī's theological contribution than it may be for that of Mechthild. Lalleśvarī is certainly an "outsider within" during her lifetime, sociologically speaking. But theologically I am not so sure. I doubt that Mechthild and Lalleśvarī depart from their traditions-as defined by the official male eliteto the same degree. Lalleśvarī was far from being an "outsider within" in terms of her theology of a dynamic nondualism that includes, rather than excludes, diversity, and my guess is that (leaving aside the harsh realities of her practical life) maintaining this theological vision was far easier for her than for Mechthild. There is, for example, no record of religious women being targeted for heresy trials and inquisitional burnings in Kashmir, as was the case for
Marguerite Porete (d. 1310), Mechthild's sister beguine. Even if-during her life-she was displaced sociologically, the Kashmiri saint is very much within her tradition theologically. The extraordinary preservation, and pervasive presence, of her sayings in Kashmiri oral tradition, and her popular status as a Kashmiri religious and cultural icon, may in part be attributed to this.

Reading this book with anything less than scrupulous attention to detail, a reader not familiar with the varieties of Hindu thought could easily get the impression that Lalleśvarî's vision of a dynamic Godhead pouring itself out into creation is singular. This of course is not the case. Although readers might be excused for missing it given the book's focus on Lalleśvarī as an individual theologian and the attendant thematization of "women's wisdom," Voss Roberts does recognize Lalleśvarī's embeddedness in her tradition. For example, she writes:

Lalleśvarī . . . is not some rare contradiction to the customary view of Eastern mysticism as nondual. Rather, she echoes the metaphysics of Kashmir Saivism-one of numerous Indian systems that define themselves against Advaita Vedanta. Lalleśvarī stands as a testament to the duality preserved in Saivism and in the oral legacies of women's wisdom in India. (3536)

This is true, to be sure, and fairly stated. I would, however, write more emphatically: Lalleśvarī testifies to the rich appreciation of dualities (not dualism) in Śaivism as a whole, in Rāmānuja, Vallabha, the Gau ìya gosvāmins, and other Hindu theologians, and in the oral/vernacular traditions of women's and men's wisdom in India.

\section{Notes}

${ }^{1}$ See, for example, Lance E. Nelson, "The dualism of nondualism: Advaita Vedānta and the irrelevance of nature," in Purifying the earthly body of God, ed. Lance E. Nelson (Albany: State University of New York Press, 1998), 61-88. 
2 One might note, however, that the "official" Kashmir Śaiva lineage of teachers contains the names of three illustrious female adepts, or yoginīs: Keyūravatī, Madanikā, and Kalyānikā (all c. 825-875 C.E.). These three women are remembered as the chief disciples of Śivānandanātha. They are said to have been the preceptors of a number of male disciples, the most famous being Govindarāja, Bhānuka, and Eraka. Nothing is known of their lives or specific teachings; neither are they known to have composed any texts important to the tradition. Nevertheless, their presence in the lineage is both interesting and suggestive. See K. C. Pandey, Abhinavagupta: An Historical and Philosophical Study, 2nd ed. (Varanasi: The Chowkhamba Sanskrit Series Office, 1963), 465; Navajivan Rastogi, The Krama Tantrism of Kashmir, vol. 1 (Delhi: Motilal Banarsidass, 1996), 90-91 and Appendix A.

${ }^{3}$ As edited by Jai Lal Kaul, Lal Ded (New Delhi: Sahitya Akademi, 1973). The other collection that I (following Voss Roberts) rely upon is that of Jaishree Kak Odin, To the Other Shore: Lalla's Life and Poetry (New Delhi: Vitastā, 1999). The full text in Devanagari script (with accents) of the verses in Kaul's edition, along with a somewhat more accessible translation, may be found in Nil Kanth Kotru, Lal Ded: Her Life and Sayings (Srinagar: Utpal Publications, 1989).

4 Following Voss Roberts, I use the abbreviations " $\mathrm{K}$ " to refer to verse numbers in Kotru's translation, and "O" for verses in Odin's.

${ }^{5}$ Ksemarāja, The Shiva Sūtra Vimarshinī, Being the Sütras of Vasu Gupta with the Commentary Called Vimarshinī, ed. Jagadish Chandra Chatterji, Kashmir Series of Texts and Studies 1 (Srinagar, Kashmir: The Archæological and Research Department, Kashmir State, 1911), 98.

6 All citations from Utpala are from Constantina Rhodes Bailly, Shaiva Devotional Songs of Kashmir: A Translation and Study of Utpaladeva's Shivastotravali, The SUNY series in the Shaiva traditions of Kashmir (Albany: State University of New York Press, 1987).

${ }^{7}$ Mañgala verse 3, in Bhaț̣anārāyaṇa and Kṣemarāja, The Stavacintāmaṇi of Bhațta Nārāyaṇa with Commentary by Kșemarāja, ed. Mukunda Rama Shastri, Kashmir Series of Texts and Studies 10 (Srinagar, Kashmir: Research Department, Jammu and Kashmir State, 1918), 1.

${ }^{8}$ Abhinavagupta, The Tantrāloka of Abhinava Gupta, with Commentary by Rājānaka Jayaratha, ed. Madhusudan Kaul Shastri, vol. 5, Kashmir Series of Texts and Studies 23 (Allahabad: The Indian Press, 1922), 2.
9 Jaideva Singh, trans., Vijnanabhairava, or Divine Consciousness: A Treasury of 112 Types of Yoga (New Delhi: Motilal Banarsidass Publ., 1979), 99 (my translation).

${ }^{10}$ Ibid., xxiv-xxvi.

${ }^{11}$ See Kaul, Lal Ded, chap. 2, for a discussion of the nature of the vākhs and the problems inherent in establishing an authentic text.

12 Odin, To the Other Shore, 67.

${ }^{13}$ Ibid., 84.

${ }^{14}$ Ibid., 82, 84.

15 Daniel Henry Holmes Ingalls, Jeffrey Moussaieff Masson, and M. V. Patwardhan, trans., The Dhvanyāloka of Ânandavardhana with the Locana of Abhinavagupta (Cambridge, Mass.: Harvard University Press, 1990), 1-39.

${ }^{16}$ Odin, To the Other Shore, 91.

17 "Her favourite expression 'śūnyas śūnyāh mīlith gav' (emptiness has merged with the emptiness) is widely relished by her readers though its actual meaning evades the understanding of most of them," S. S. Toshkhani, "Spiritual Journey of Lal Ded," Blog, Heritage Kashmir, June 3, 2011, http://heritagekashmir.blogspot.com

/2007/10/spiritual-journey-of-lal-ded.html.

${ }^{18}$ Pandey, Abhinavagupta, 21; Paul Eduardo MullerOrtega, The Triadic Heart of Siva: Kaula Tantricism of Abhinavagupta in the Non-Dual Shaivism of Kashmir, The SUNY series in the Shaiva traditions of Kashmir (Albany: State University of New York Press, 1989), 45-46.

${ }^{19}$ Odin, To the Other Shore, 92.

${ }^{20}$ Triloki Nath Dhar, Rupa Bhawani, Life, Teachings \& Philosophy (Srinagar: All India Saraswat Cultural Organization, Jammu \& Kashmir Region, 1977), 811; Aparna Dhar, "The Life of Devi Roop Bhawani," Kashmiri Saints \& Sages: Ancient \& Modern Ascetics in Kashmir, n.d., http://www.koausa.org/Saints/RupaBhawani/article3. html. 